\title{
Editorial
}

\section{Stories and transformations}

Stories, Norman and Jennifer Provizer tell us in this issue of Leadership and the Humanities, 'play a critical role in what it means to be human.' The storytelling impulse, for both tellers and their audiences, shapes meanings and draws lessons out of complex, multivalent, ambiguous realities. Provizer and Provizer note Nassim Taleb's (2010) caution that our craving for stories risks a 'narrative fallacy,' the preference for 'compact stories over raw truths.' But, as Provizer and Provizer demonstrate in their exploration of a tangle of narratives involving the Russian novelist Leo Tolstoy, the American President Abraham Lincoln, and the nineteenth-century Avar military leader Hadji Murád, the impulse to tell stories, and to read the lives of leaders as dramatic stories with narrative trajectories and comprehensible values, examples, and dramatic moments, is a key part of how we make sense of leaders. Provizer and Provizer remind us that Tolstoy himself, despite typically being cited by leadership scholars as exemplifying an impersonal, forces-of-history, anti-'great man' approach to leadership, was himself a novelist, a teller of stories about individuals - and one who, in the case of both Abraham Lincoln and Hadji Murád, believed in the truth and significance of the stories of exceptional, even heroic individuals.

Drawing on historical accounts and social-scientific research and data, Carlos Guevara Mann examines the careers and legacies of two charismatic leaders in twentieth-century Latin America, Panama's Arnulfo Arias and Puerto Rico's Luis Muñoz Marín, to explore whether charismatic leadership can contribute over the long term to democracy-building. In political science, charisma is looked at askance, and there is a long-standing preference for institution-building over personal leadership as a stable basis for political authority, representation, and governance. In Latin America, especially, long traditions of assertions of charismatic authority, from caudillismo to Chavismo, provide sobering lessons in the democratic limits of charisma. But Guevara Mann provides grounds for cautious optimism on the possible benefits of charismatic leadership. He distinguishes between his two subjects, and his mixed verdict on Panama's Arias is especially interesting. Arias, says Guevara Mann, developed a 'plebiscitarian' model of democracy, emphasizing 'vertical accountability' between leader and people, policed chiefly by elections, and diminishing or discarding 'horizontal accountability,' the ongoing check-andbalance functioning of institutional rivals to the chief executive such as other branches of government, independent government agencies, and a central bank. Indeed, Guevara Mann argues that several sustained phases in Panama's history (de facto rule, 1941-1945; National Police 'meddling' in politics, 1947-1955; and military dictatorship, 1968-1989), show how Arias's cultivation of 'plebiscitary' or top-down democracy contributed to anti-democratic rule. Still, Guevara Mann judges that Arias's charismatic appeal had positive value for the long, uncertain development of democracy in Panama: 'Over the long military period, Arias's 
charismatic leadership became the emblem of civilian and constitutional rule against a repressive and venal military regime.' And, in a conclusion that recalls Provizer and Provizer's exploration of the power of leadership stories, Guevara Mann says that late in life, as a presidential candidate in 1984, Arias became a 'living symbol' of democratic governance. 'In this way,' Guevara Mann concludes, 'despite old age, Arias contributed to keep the yearning for democracy alive in Panama during a nondemocratic epoch. This was, perhaps, the greatest service he provided his country.' In becoming a symbol of democracy, Arias's charismatic energy became attached to something more enduring than the single, inspirational individual: a fascinating transmutation of charisma, and a reminder that stories and symbols are not simply told by the tellers, but felt and sparked into power by those who perceive and choose to believe them.

The authors of our next paper, Manuela Ortega-Ruiz and Francisco Javier LuqueCastillo, compare Adolfo Suárez and Felipe González, two key Spanish leaders in the transition to democracy after the long military rule of Francisco Franco. Suárez was Spain's first democratically elected Prime Minister in the post-Franco era, serving from 1976 to 1981. González served in that office from 1982 to 1996, the longest tenure of any elected Spanish prime minister. Using discourse analysis, Ortega-Ruiz and Luque-Castillo suggest that González's greater ability to forge connections with the Spanish people strengthened his hold on his office. Drawing on the seminal work of Shamir et al. $(1993 ; 1994)$, they identify three key elements in Gonzalez's frequent speeches and addresses to the people: personal effort, faith in a better future, and past and present values, all expressed in ways that resonated with the Spanish populace. They assess Suárez, by contrast, as having pursued a more squarely 'pragmatic' communicative strategy, largely eschewing 'feelings or high expectations,' and avoiding 'great promises.' In short, their comparison of these two important Spanish statesmen suggests leaders who adopt a transformational communicative strategy emphasizing 'collective identity, common effort, empowerment of followers, and an exciting future' may be more likely to forge strong connections with followers than leaders who are more narrowly transactional in their discourse.

In our final research paper, Cheryl Patton takes on the topic of transformational leadership but turns it inward, to explore how two of the stories of two iconic ancient leaders, Asoka in India and Paul in the early Christian church, show a turn from violence and force to example and inspiration. The young Asoka launched aggressive wars of conquest against Kalinga and other neighboring kingdoms. Paul, before his conversion, when he still bore the name of Saul and identified as a Jew, 'made havoc of the church, entering every house, and dragging off men and women, committing them to prison,' according to the New Testament (Acts 3:8). But at critical points in both their lives, these formidable and forceful individuals embraced new religious identities - Asoka embracing Buddhism, and Saul taking on a new identity as Paul, apostle of Christianity. These personal transformations, Patton argues, as well as their 'tenacity in promoting their visions,' became a central part their own leadership stories - and an important wellspring for the lessons they taught, and the legacies they established. Asoka and Paul, Patton notes, played critical roles in spreading major world religions, Buddhism in Asia and Christianity throughout the Roman Empire.

In a provocative opinion piece, Peter Kaufman advocates for a vision of humanities education centered on 'transgressive teaching': pushing undergraduate students, even to the point of seeming rudeness, to challenge received opinions and think for themselves. We may think of the humanities as distant from the technical and instrumental content of "pre-professional, para-professional, and professional undergraduate 
programs.' But the fundamental humanities habits of careful reading and persistent questioning, Kaufman says, are especially important for young people in such programs, because the humanities, well taught, compel attention to issues of identity, purpose, community, justice, and responsibility. Kaufman punctuates his argument with pithy advice from Oliver Wendell Holmes to a Harvard senior: life, Holmes said, 'is painting a picture, not doing a sum.'

Then comes a brief interview with the noted scholar of the humanities and culture, Camille Paglia, who answers three questions about leadership. Paglia, while conceding that human beings are not 'prisoners of biology,' nevertheless suggests that traditionally 'male' patterns of leadership may have a lot to teach any aspiring leader today, regardless of gender, and that in particular military leadership merits thoughtful study, not simply condemnation as relics of a past, unenlightened age.

The issue closes with lucid reviews by two gifted scholars, Joseph Prud'homme and Janet Sutherland, of two remarkable recent leadership books, Mark Menaldo's (2013) fascinating study of 'transformative ambition' and realism in Pericles and other notable leaders, and Nathan Harter's (2015) ambitious and impressive philosophical exploration of the leader's mind.

Michael Harvey

\section{REFERENCES}

Harter, Nathan W. (2015), Leadership and Coherence: A Cognitive Approach, New York: Routledge.

Menaldo, Mark A. (2013), Leadership and Transformative Ambition in International Relations, Cheltenham, UK and Northampton, MA: Edward Elgar.

Shamir, B., Arthur, M.B., and House, R.J. (1993), 'The motivational effects of charismatic leadership: a self-concept based theory,' Organization Science, 4(4), 577-594.

Shamir, B., Arthur, M.B., and House, R.J. (1994), 'The rhetoric of charismatic leadership: a theoretical extension, a case study, and implications for research,' Leadership Quarterly, $5(1), 25-42$.

Taleb, Nassim (2010), The Black Swan: The Impact of the Highly Improbable, New York: Random House. 